\title{
KEMAMPUAN MELAKUKAN PENATALAKSANAAN HIPOGLIKEMIA BERDASARKAN KARAKTERISTIK DAN PENGETAHUAN PASIEN DIABETES MELITUS
}

\author{
Ernawati $^{1 *}$ \\ 1. Program Studi Ilmu Keperawatan Fakultas Kedokteran dan Ilmu Kesehatan Universitas Islam Negri Syarif Hidatatullah, \\ Jl. Kertamukti Ciputat, Jakarta 15412, Indonesia \\ *Email: ernawatifkik@yahoo.com
}

\begin{abstract}
Abstrak
Kadar glukosa darah terlalu rendah akan membahayakan tubuh karena dapat merusak jaringan otak yang bersifat irreversible. Penelitian ini bertujuan mengetahui hubungan antara karakteristik dan pengetahuan pasien diabetes dengan kemampuan melakukan penatalaksanaan hipoglikemia. Metode penelitian ini adalah cross sectional dengan sampel 50 pasien diabetes yang pernah mengalami hipoglikemia. Hasil penelitian menunjukkan mayoritas responden kurang mendapatkan dukungan keluarga dan memiliki pengetahuan yang kurang tentang penatalaksanaan hipoglikemia sebesar 30 orang (60\%). Sebagian besar responden yaitu 28 orang (56\%) tidak mampu melakukan penatalaksanaan hipoglikemia dengan baik. Hasil penelitian juga menunjukkan karakteristik pasien diabetes yang berhubungan dengan kemampuan penatalaksanaan hipoglikemia meliputi usia ( $r=-0,28, p=0,046, \alpha=0,05)$, lama menderita diabetes $(r=0,424, p=0,002, \alpha=0,05)$, dukungan keluarga $(p=0,035$, $\alpha=0,05)$, pendidikan ( $p=0,034, \alpha=0,05)$, pengetahuan hipoglikemia ( $\mathrm{p}=0,0005, \alpha=0,05)$. Peneliti menyarankan pemberian asuhan keperawatan berupa pendidikan kesehatan tentang hipoglikemia, hendaknya dilakukan secara dini sejak pasien terdeteksi diabetes dan berfokus pada kemandirian dalam mendeteksi dan penanganan hipoglikemia.
\end{abstract}

Kata kunci: penatalaksanaan hipoglikemia, pengetahuan hipoglikemia, usia, lama menderita diabetes, dukungan keluarga

\begin{abstract}
The state of low blood glucose level is dangerous because in the state of hypoglycemia the brain tissues are vulnerable and the damage to nerve tissue is irreversible. This research aims in describing the factors related with diabetes patients' ability in managing hypoglycemia. The method of the research is cross sectional with 50 patients who have undergone hypoglycemia as the samples. The results showed a majority of respondents have less family support and have less knowledge about the management of hypoglycaemia by 30 people (60\%). The majority of respondents ie 28 people (56\%) are unable to perform the management of hypoglycemia as well. The result of the research also shows that the factors related to hypoglycemia management are age $(r=-0.28, p=0,046, \alpha=0,05)$, the duration of diabetes $(r=0,424$, $p=0,002, \alpha=0,05)$, family support $(p=0,035, \alpha=0,05)$, education $(p=0,034, \alpha=0,05)$, hypoglycemia knowledge $(p=$ $0,0005, \alpha=0,05)$. The researcher suggess to delivering nursing care about hypoglycemia's management health education. This education should give as early as patient detected from diabetes, and focusing on self care in hypoglycemia detection and management.
\end{abstract}

Keywords: hypoglycemia of management, hypoglycemia of knowledge, age, duration of diabetes, family support.

\section{Pendahuluan}

Hipoglikemia terjadi ketika glukosa darah kurang dari 50 sampai $60 \mathrm{mg} / \mathrm{dl}$. Prevalensi hipoglikemia cukup tinggi, kurang lebih $90 \%$ pasien yang mendapatkan terapi insulin pernah mengalami hipoglikemia. Peningkatan prevalensi dan resiko hipoglikemia berat berkaitan erat dengan kemampuan penderita diabetes dalam mengelola penyakitnya. Perkembangan hipoglikemia ke dalam keadaan yang lebih berat dapat dicegah dengan peningkatan kemampuan penderita DM mengontrol glukosa darah, deteksi dini terjadi hipoglikemia, dan penatalaksanaan yang tepat sehingga komplikasi yang lebih berat dapat dicegah (Smeltzer, 2008).
Perawat sebagai ujung tombak pelayanan kesehatan memiliki peran sebagai educator dan konselor dalam meningkatkan kemandirian pasien dan keluarga untuk mengidentifikasi penyebab, gejala dan tindakan koreksi serta pencegahan hipoglikemia yang lebih berat (Hudak \& Gallo, 2005).

\section{Metode}

Metode penelitian ini adalah cross sectional dengan sampel 50 pasien diabetes yang pernah mengalami hipoglikemia. Penelitian ini bertujuan mengetahui hubungan antara karakteristik dan pengetahuan pasien diabetes melitus dengan kemampuan melakukan penatalaksanaan hipoglikemia. 


\section{Hasil}

Tabel 1. Karakteristik responden

\begin{tabular}{cc}
\hline Usia (Mean \pm SD) & $59,9 \pm 9,234$ \\
CI 95\% & $57,27-62,53$ \\
Min-Mak & $32-76$ \\
Lama DM (Mean \pm SD) & $5,75 \pm 7,144$ \\
CI 95\% & $3,720-7,780$ \\
Min-Mak & $0,5-30$ \\
Tingkat pendidikan (\%) & \\
Pendidikan das ar & $36(72 \%)$ \\
Pendidikan lanjut & $14(28 \%)$ \\
Dukungan keluarga (\%) & \\
Kurang & $34(68 \%)$ \\
Baik & $16(32 \%)$ \\
Tingkat pengetahuan $(\%)$ & \\
Kurang & $\mathbf{3 0}(\mathbf{6 0 \%})$ \\
Baik & $\mathbf{2 0}(\mathbf{4 0 \%})$ \\
Kurang & $\mathbf{2 8}(\mathbf{5 6 \%})$ \\
Baik & $\mathbf{2 2 ( 4 4 \% )}$ \\
\hline
\end{tabular}

Tabel 1 menjelaskan rata-rata usia responden 59,90 tahun dengan standar deviasi 9,243 tahun. Rerata durasi atau lama menderita DM adalah 5,75 tahun dengan standar deviasi 7,144 tahun. Distribusi frekuensi tingkat pendidikan responden yang paling banyak adalah berpendidikan dasar (tidak sekolah, SD dan SMP) sebanyak 36 orang $(72,0 \%)$.

Hasil penelitian menunjukkan bahwa mayoritas responden kurang mendapatkan dukungan keluarga. Di antara 50 klien diabetes yang memiliki dukungan keluarga kurang terdapat 34 orang $(68.0 \%)$, sedangkan yang memiliki dukungan keluarga baik terdapat 16 orang $(32 \%)$.

Mayoritas responden memiliki pengetahuan yang kurang tentang penatalaksanaan hipoglikemia sebesar 30 orang $(60 \%)$, sedangkan yang memiliki pengetahuan baik tentang penatalaksanaan hipoglikemia sebesar 20 orang (40\%). Sebagian besar responden tidak mampu melakukan penatalaksanaan hipoglikemia dengan baik. Jumlah responden yang memiliki kemampuan melakukan penatalaksanaan hipoglikemia sebesar 22 orang $(44 \%)$.

Tabel 2. Hubungan usia dengan kemampuan penatalaksanaan hipoglikemia

\begin{tabular}{lcclc}
\hline Variabel & $\mathrm{R}$ & $\mathrm{R}^{2}$ & \multicolumn{1}{c}{ Persamaan } & $\mathrm{p}$ \\
\hline Usia & $-0,284$ & 0,097 & $\begin{array}{l}\text { Kemampuan Penatalaksanaan } \\
\text { Hipoglikemia = 1,453-0,17 Usia }\end{array}$ & 0,046 \\
& & & \\
\hline
\end{tabular}

Terdapat hubungan antara usia dan kemampuan penatalaksanaan hipoglikemia $(p=0,046, \alpha=0,05)$ dan berpola negatif, artinya semakin muda usia responden maka semakin meningkat kemampuan melakukan penatalaksanaan hipoglikemia. Nilai koefisien determinasi 0,097 artinya persamaan garis regresi yang diperoleh dapat menerangkan 9,7\% variasi kemampuan penatalaksanaan hipoglikemia.

Terdapat hubungan antara durasi diabetes dengan kemampuan penatalaksanaan hipoglikemia $(\mathrm{p}=0,002, \alpha=0,05)$ dan berpola positif, artinya semakin lama durasi diabetes maka semakin meningkat kemampuan melakukan penatalaksanaan hipoglikemia. Nilai koefisien determinasi 0,021 artinya persamaan garis regresi yang diperoleh dapat menerangkan $2,1 \%$ variasi kemampuan penatalaksanaan hipoglikemia.

Hasil penelitian menunjukkan bahwa di antara 50 responden, ada $12(33,3 \%)$ responden yang pendidikan dasar memiliki kemampuan penatalaksanaan tentang hipoglikemia. Sedangkan responden yang berpendidikan lanjut sebanyak 10 $(71,4 \%)$ responden yang memiliki kemampuan penatalaksanaan hipoglikemia.

Hasil uji statistik dapat disimpulkan bahwa ada perbedaan kemampuan penatalaksanaan hipoglikemia antara pendidikan dasar dan pendidikan lanjut penderita diabetes $(\mathrm{p}=0,034, \alpha=0,05)$. Dari hasil analisis diperoleh pula nilai $\mathrm{OR}=5,000$, artinya Klien yang berpendidikan tinggi memiliki peluang 5 $\mathrm{x}$ untuk mampu melakukan penatalaksanaan hipoglikemia dibandingkan dengan klien yang berpendidikan rendah.

Hasil penelitian menunjukkan bahwa di antara 50 responden, ada $11(68,8 \%)$ responden yang memiliki dukungan keluarga baik memiliki kemampuan penatalaksanaan tentang hipoglikemia. Sedangkan responden yang memiliki dukungan keluarga kurang sebanyak $11(32,4 \%)$ responden yang memiliki kemampuan penatalaksanaan hipoglikemia.

Hasil uji statistik dapat disimpulkan bahwa ada perbedaan kemampuan penatalaksanaan hipoglikemia antara responden diabetes yang memiliki dukungan keluarga dan yang tidak memiliki dukungan keluarga $(\mathrm{p}=0,035, \alpha=0,05)$. 
Dari hasil analisis diperoleh pula nilai $\mathrm{OR}=4,600$, artinya Klien yang memiliki dukungan keluarga mempunyai peluang 4,6 x untuk mampu melakukan penatalaksanaan hipoglikemia dibandingkan dengan klien yang berpendidikan rendah.

Pada tabel 3 menunjukkan bahwa di antara 50 responden, ada $3(10 \%)$ responden yang memiliki pengetahuan kurang tentang hipoglikemia mempunyai kemampuan penatalaksanaan tentang hipoglikemia. Sedangkan responden yang memiliki pengetahuan baik tentang hipoglikemia sebanyak 19 (95\%) responden yang memiliki kemampuan penatalaksanaan hipoglikemia.

Hasil uji statistik dapat disimpulkan bahwa ada perbedaan kemampuan penatalaksanaan hipoglikemia antara responden klien diabetes yang memiliki pengetahuan baik tentang penatalaksanaan hipoglikemia dan klien diabetes yang kurang memiliki pengetahuan tentang penatalaksanaan hipoglikemia $(p=0,0005, \alpha=0,05)$.

Dari hasil analisis diperoleh pula nilai $\mathrm{OR}=171$, artinya klien yang memiliki pengetahuan baik mempunyai peluang 171 kali untuk mampu melakukan penatalaksanaan hipoglikemia dibandingkan dengan klien yang memiliki pengetahuan kurang.

\section{Pembahasan}

Usia lansia dicirikan dengan seringnya lansia mengeluhkan kesehatannya karena penurunan fungsi tubuh dan intelektual karena adanya proses penuan yang dialami setiap orang (David, 1972, dalam Juliani, 2005). Hasil analisa bivariat menunjukkan terdapat hubungan antara usia dan kemampuan penatalaksanaan hipoglikemia dan berpola negatif, artinya semakin muda usia responden maka semakin meningkat kemampuan melakukan penatalaksanaan hipoglikemia.
Resistensi insulin cenderung meningkat pada usia di atas 65 tahun. Pada usia lanjut, sensitivitas reseptor jaringan perifer terhadap insulin mengalami penurunan. Hal ini berarti sel-sel otot dan lemak pasien lanjut usia kepekaannya menurun terhadap insulin. Menurut Brunner dan Suddart (2000) menyebutkan bahwa insiden penyakit DM tipe 2 muncul di atas umur 30 tahun. Hasil penelitian mendapatkan bahwa umur di antara 40-60 tahun merupakan kelompok umur paling banyak di antara pasien yang mengalami DM tipe 2 (Timby,et al, 1999). Resistensi insulin cenderung meningkat pada usia di atas 65 tahun. Pada lansia, sensitivitas reseptor jaringan perifer terhadap insulin mengalami penurunan.

Lansia lebih beresiko mengalami penurunan fungsi mekanisme counterregulatory dan penurunan kognitif. Penurunan fungsi mekanisme counterregulatory menyebabkan frekuensi hipoglikemia meningkat, dan penurunan kognitif pada lansia mengakibatkan kegagalan mengenal gejala hipoglikemia, sehingga kemampuan penatalaksanaan hipoglikemia juga mengalami penurunan.

Hasil analisa bivariat penelitian menunjukkan bahwa di antara 50 responden, ada $12(33,3 \%)$ responden yang pendidikan dasar memiliki kemampuan penatalaksanaan tentang hipoglikemia. Sedangkan responden yang berpendidikan lanjut sebanyak 10 $(71,4 \%)$ responden yang memiliki kemampuan penatalaksanaan hipoglikemia.

Hasil uji statistik dapat disimpulkan bahwa ada perbedaan kemampuan penatalaksanaan hipoglikemia antara pendidikan dasar dan pendidikan lanjut penderita diabetes ( $p=0,034, \alpha=0,05)$. Dari hasil analisis diperoleh pula nilai $\mathrm{OR}=5,000$ artinya klien yang berpendidikan tinggi memiliki peluang $5 \mathrm{x}$ untuk mampu melakukan penatalaksanaan hipoglikemia dibandingkan dengan klien yang berpendidikan rendah.

Tabel 3. Hubungan antara pengetahuan klien diabetes dengan kemampuan penatalaksanaan hipoglikemia

\begin{tabular}{|c|c|c|c|c|c|c|c|c|}
\hline \multirow{4}{*}{ Pengetahuan klien } & \multirow{2}{*}{\multicolumn{4}{|c|}{$\begin{array}{c}\text { Kemampuan pe natalaksanaan } \\
\text { hipoglikemia }\end{array}$}} & \multirow{2}{*}{\multicolumn{2}{|c|}{ Total }} & \multirow{4}{*}{$\begin{array}{c}\text { OR } \\
(95 \% \text { CI })\end{array}$} & \multirow{4}{*}{$\mathbf{p}$} \\
\hline & & & & & & & & \\
\hline & \multicolumn{2}{|c|}{ Mampu } & \multicolumn{2}{|c|}{ Tidak mam pu } & \multirow[b]{2}{*}{$\mathbf{n}$} & \multirow{2}{*}{$\%$} & & \\
\hline & $\mathbf{n}$ & $\%$ & $\mathbf{n}$ & $\%$ & & & & \\
\hline Kurang & 3 & 10 & 27 & 90 & 30 & 100 & 171,000 & 0,0005 \\
\hline Baik & 19 & 95 & 1 & 5 & 20 & 100 & $16,504-1771,705$ & \\
\hline Total & 22 & 44 & 28 & 56 & 50 & 100 & & \\
\hline
\end{tabular}


Penelitian ini didukung oleh penelitian yang dilakukan Setyawati (2000) bahwa terdapat hubungan antara tingkat pendidikan formal dengan keteraturan pemeriksaan kadar gula darah. Penderita diabetes yang teratur memeriksa kadar gula darahnya akan lebih mengetahui fluktuasi kadar gula darahnya sehingga lebih dapat mengantisipasi keadaanya jika terjadihipoglikemia.

Tingkat pendidikan umumnya akan berpengaruh terhadap kemampuan seseorang dalam memahami suatu informasi. Menurut Notoatmodjo (2003) bahwa pengetahuan merupakan faktor predisposisi pada pembentukan perilaku kesehatan, dalam hal ini yaitu perilaku kepatuhan pasien DM dalam memelihara kesehatannya.

Tingkat pendidikan termasuk faktor predisposisi yang menjelaskan bahwa semakin tinggi pendidikan seseorang lebih dapat menerima pembelajaran yang berhubungan dengan praktek pengukuran makanan/ diet dengan benar/ tepat. Hal ini sesuai dengan hasil penelitian Dewi, dkk (2008) bahwa responden yang menempuh lama pendidikan formal $<9$ tahun lebih banyak melakukan kesalahan praktek pengukuran makanan/dietnya yaitu sebanyak 35 orang $(62,5 \%)$ dibanding dengan responden yang menempuh pendidikan formal e" 9 tahun.

Hipoglikemia unawareness (Hipoglikemia yang tidak disadari) dapat terjadi akibat kegagalan proteksi fisiologis atau kegagalan mekanisme counteregulatory. Hampir semua pasien diabetes mellitus yang mendapat terapi insulin mengalami gangguan pada mekanisme proteksi terhadap hipoglikemia yang berat, walaupun dengan derajat yang berbeda.

Saat diagnosis DM dibuat, respon glukagon terhadap hipoglikemia umumnya normal. Respon glukagon pada pasien DM tipe 1 mulai turun setelah menderita diabetes 1-2 tahun, dan setelah 5 tahun respon glukagon tersebut hilang. Penyebab kegagalan respon tersebut saat ini belum diketahui secara pasti, diperkirakan tidak berkaitan dengan neuropati otonomik atau kendali glukosa yang ketat.

Sel secara selektif gagal mendeteksi adanya hipoglikemia dan tidak dapat menggunakan hipoglikemia sebagai rangsangan untuk mensekresi glukagon, walaupun sekresi yang glukagon masih dapat dirangsang oleh perangsang lain seperti alanin. Diabetes yang berlangsung lama sering dijumpai penurunan respon simpatoadrenal walaupun dengan tingkat gangguan yang bervariasi (Sudoyo, 2006).

Penelitian yang dilakukan Lin, et al., (2010) pada pasien diabetes yang dirawat dirumah sakit menunjukkan bahwa durasi lamanya menderita DM, leukositosis, hipoalbuminemia, dan penggunaan obat tertentu seperti, beta-blocker, dan diuretik, akan mengakibatkan pasien cenderung mengalami hipoglikemia berulang selama perawatan di rumah sakit. Hal ini terkait dengan penurunan fungsi mekanisme counterregulatory, tingkat albumin yang rendah termasuk peradangan, infeksi, dan trauma (Lin, et al., 2010).

Hasil penelitian menunjukkan ada perbedaan kemampuan penatalaksanaan hipoglikemia antara responden diabetes yang memiliki dukungan keluarga dan yang tidak memiliki dukungan keluarga $(\mathrm{p}=$ $0,035, \alpha=0,05)$. Dari hasil analisis diperoleh pula nilai $\mathrm{OR}=4,600$, artinya Klien yang memiliki dukungan keluarga mempunyai peluang 4,6 x untuk mampu melakukan penatalaksanaan hipoglikemia dibandingkan dengan klien yang berpendidikan rendah.

Menurut Tjokroprawiro (2001) kepribadian atau motivasi penderita untuk mentaati diet, terapi dan latihan gerak badan dari dokter yang merawatnya dan sadar semua itu untuk kepentingan dirinya sendiri merupakan factor kunci untuk menilai keterawatan penderita DM. Apabila penderita mempunyai motivasi yang baik, maka dapat diyakini kalau hasil pengukuran glukosa darah menggambarkan keadaan sebenarnya.

Keluarga sebagai salah satu lingkungan sosial terdekat dengan penderita DM merupakan satu faktor yang potensial untuk mempengaruhi dan membentuk motivasi yang sehat bagi penderita DM dalam menjalankan penatalaksanaan DM. Faktor sikap, perilaku, dan partisipasi keluarga penderita DM merupakan faktor penting untuk menentukan keberhasilan penatalaksanaan DM. Penatalaksanaan pada pasien DM ini bertujuan untuk pengendalian kadar gula darah penderita (Tjokroprawiro, 2001 dalam Rinto,2008). 
American Diabetes Association (ADA, 2006) mengatakan bahwa perencanaan pengelolaan diabetes harus dibicarakan sebagai terapetik individual antara pasien dan keluarganya dan pasien harus menerima perawatan medis secara terkoordinasi dan integrasi dari tim kesehatan, sehingga keluarga menyadari pentingnya keikutsertaan dalam perawatan penderita diabetes mellitus agar kadar gula darah penderita dapat terkontrol dengan baik. Untuk mempertahankan kadar gula darah penderita dalam batas normal pada prinsipnya diletakkan pada tatalaksana pengaturan diet, olah raga, obat anti diabetik, penilaian kontrol dan edukasi.

Di lihat dari hasil penelitian Rinto (2006) dapat dilihat bahwa sebagian besar penderita DM tipe 2 kadar gula darahnya masih dikatakan buruk dengan persentase $54,3 \%$. Hal ini dapat memberikan arti bahwa tatalaksana penderita DM yang bertumpu pada peran serta keluarga belum berjalan dengan semestinya.

Namun demikian potensi keluarga sebagai dasar perawatan penderita DM masih dapat dikembangkan, dengan asumsi dari hasil penelitian diperoleh sikap keluarga dengan perilaku keluarga $\mathrm{p}<0,01$, perilaku keluarga dengan partisipasi $\mathrm{p}<$ 0,01 , sehingga memperlihatkan hubungan yang positif antara sikap keluarga dengan perilaku keluarga maupun perilaku keluarga dengan partisipasinya.

Untuk partisipasi keluarga dalam pemenuhan kesehatan ditentukan salah satunya oleh predisposisi keluarga untuk menggunakan pelayanan kesehatan yang meliputi umur, jenis kelamin, besarnya keluarga serta hubungan keluarga dalam pelayanan kesehatan. Menurut Ismail dalam Rinto,2008 keadaan diatas dapat terjadi karena banyak adanya confinding factors yang berpengaruh dalam hubungan itu, menurutnya sikap seseorang terhadap suatu obyek distimulir oleh pola pikir individu, isu - isu sosial dan situasi kelompok sosial yang ada.

Hasil penelitian menunjukkan bahwa di antara 50 responden, ada $3(10 \%)$ responden yang memiliki pengetahuan kurang tentang hipoglikemia mempunyai kemampuan penatalaksanaan tentang hipoglikemia. Sedangkan responden yang memiliki pengetahuan baik tentang hipoglikemia sebanyak
$19(95 \%)$ responden yang memiliki kemampuan penatalaksanaan hipoglikemia.

Hasil uji statistik menunjukkan adanya perbedaan kemampuan penatalaksanaan hipoglikemia antara responden diabetes yang memiliki pengetahuan baik tentang penatalaksanaan hipoglikemia dan yang kurang memiliki pengetahuan tentang penatalaksanaan hipoglikemia ( $\mathrm{p}=0,0005, \alpha=0,05)$. Dari hasil analisis diperoleh pula nilai OR $=171$, artinya Klien yang memiliki pengetahuan baik mempunyai peluang $171 \mathrm{x}$ untuk mampu melakukan penatalaksanaan hipoglikemia dibandingkan dengan klien yang memiliki pengetahuan kurang

Pengetahuan merupakan salah satu faktor yang mendukung dalam melakukan perawatan diri seharihari karena dengan pengetahuan yang cukup seseorang akan memahami kondisi sakitnya dan diharapkan mampu mengelola diri agar senantiasa berpola hidup sehat sehingga gula darah terkontrol.

Penelitian Rahmadiliyani (2007) yang berjudul hubungan antara pengetahuan tentang penyakit dan komplikasi pada penderita DM dengan tindakan mengontrol gula darah diwilayah kerja puskesmas I gatak sukaharjo, didapatkan hasil ada hubungan yang signifikan antara pengetahuan dengan tindakan mengontrol gula darah denga nilai $r=0,508$.

Penelitian ini sesuai dengan penelitian Dewi (2008) dimana responden yang berpengetahuan kurang berpeluang melakukan kesalahan pengukuran makanan/dietnya sehari-hari sebesar 14,01 kali (95\% CI : 4,70-41,75) dibandingkan dengan responden yang bepengetahuan baik. Kesalahan pengukuran merupakan salah satu penyebab terjadinya hipoglikemia, sehingga diperlukan kemampuan penderita diabetes untuk mengatasi hipoglikemia guna mencegah komplikasi yang lebih fatal.

Faktor-faktor seperti kesalahan diet, konsumsi alcohol, aktifitas yang berlebihan, kurangnya kemauan diri untuk melakukan perawatan diri sendiri, hal tersebut merupakan risiko yang dapat menyebabkan terjadinya hipoglikemia. Risiko-risiko tersebut dapat di cegah dengan memberikan edukasi kesehatan tentang penatalaksanaan hipoglikemia (Boyle, et al. 2007). 


\section{Kesimpulan}

Karakteristik responden yang berhubungan dengan kemampuan penatalaksanaan hipoglikemia adalah pengetahuan tentang hipoglikemia, usia, pendidikan, lama menderita diabetes dan dukungan keluarga. Hasil penelitian diharapkan sebagai salah satu pertimbangan dalam membuat perencanaan asuhan keperawatan dalam upaya untuk meningkatkan pengetahuan sehingga pasien dapat melakukan penanganan hipoglikemia dengan baik dan pada akhirnya komplikasi yang lebih berat dapat dihindari.

Kemampuan pasien dapat ditingkatkan dengan memberikan pendidikan kesehatan tentang penatalaksanaan hipoglikemia. Tujuan pendidikan kesehatan untuk meningkatkan pengetahuan penderita DM agar dapat melakukan self management dalam penatalaksanaan DM, termasuk penatalaksanaan hipoglikemia. Pemberian asuhan keperawatan berupa pendidikan kesehatan tentang hipoglikemia, hendaknya dilakukan secara dini sejak pasien terdeteksi diabetes dan berfokus pada kemandirian dalam mendeteksi sekaligus menangani hipoglikemia. Peran serta keluarga perlu ditingkatkan dalam penatalaksanaan hipoglikemia guna mencegah komplikasi yang lebih buruk (TN).

\section{Referensi}

American Diabetes Association. (2006). Diagnosis and classification of diabetes mellitus. Diabetes care, 27 (1), S5-S10. Diperoleh dari http:// www.care.diabetesjournal.

Boyle, P.J., \& Zrebiec, J. (2007). Physiological and behavioral aspects of glycemic control and hypoglycemia in diabetes. Diperoleh dari www.ncbi.nlm.nih.gov/pubmed/17330688.

Brunner, \& Suddart. (2000). Buku ajar keperawatan medikal bedah (volume 2) (Edisi 8). Jakarta: EGC.

Dewi, P., \& Anugraheni, K. (2008). Faktor-faktor yang mempengaruhi praktek pengukuran makanan (Diet) sehari-hari pada pasien DM tipe 2. Jurnal Epidemiologi. Tidak dipublikasikan.
Hudak, C.M., \& Gallo, B.M. (2005). Critical care nursing: A holistik approach (6th Edition). Philadelphia: Lippincott Company.

Juliani, P. (2005). Fungsi kognitif masa dewasa lanjut. Diperoleh dari http://www.psikologi ums.net $/ \mathrm{mod}$.

Lin, Y.Y., et al.(2010). Risk factors for recurrent hypoglycemia in hospitalized diabetic patients admitted for severe hypoglycemi. Diperoleh dari http://www.eymj.org.

Notoatmodjo, S. (2003). Pendidikan dan perilaku kesehatan. Jakarta: Rineka Cipta.

Rahmadiliyani. (2007). Hubungan antara pengetahuan tentang penyakit dan komplikasi pada penderita DM dengan tindakan mengontrol gula darah diwilayah kerja puskesmas I gatak sukaharjo. Tesis tidak dipublikasikan.

Rinto, N., et al. (2006). Hubungan antara sikap, perilaku dan partisipasi keluarga terhadap kadar gula darah penderita diabetes melitus tipe 2 di RS PKU Muhammadiyah Yogyakarta 2008. Diperoleh dari http://www.fkm.undip.ac.id.

Setyawati. R. (2000). Beberapa faktor yang berhubungan dengan keteraturan pemeriksaan kadar gula darah pada penderita diabetes mellitus di Rumah Sakit Umum Kota Semaran. Diperoleh dari www.fkm.undip.ac.id.

Smeltzer, S.C., Bare, B.G.., Hinkle, J.L., Cheever, K.H. (2008). Brunner \& Suddarth's textbook of medical-surgical nursing (11th Edition). Philadhelpia: Williams and Wolter Kltwer Bussiness.

Sudoyo, A.W., Setyohadi, B., Alwi, I., Simadibrata, M., Setiati, S. (2006). Ilmu penyakit dalam (Edisi 3). Jakarta: Departemen Ilmu Penyakit Dalam Fakultas Kedokteran Universitas Indonesia.

Timby, B.K., Scherer, J.C., \& Smith, N.E. (1999). Medical surgical nursing: Introductory (7th Edition). Philadelphia: Lippincott.

Jangan batasi kebaikan yang bisa Anda lakukan

karena itu akan membatasi kebesaran yang bisa Anda capai.

- Mario Teguh - 